\title{
A preliminary study on the influences of ecotourism activities to the stand structure of protected forests of Taman Negara Pahang
}

\begin{abstract}
A preliminary study on the influences of ecotourism activities on forest stand structure was carried out in the protected forests of Taman Negara Pahang. Forest stand attributes data were collected from Kuala Keniam and Lata Berkoh areas which comprised of two different conditions (known as natural and disturbed areas) with the size of plots of $20 \mathrm{~m} \times 25 \mathrm{~m}$. All trees greater than $1 \mathrm{~cm}$ in diameter at breast height $(\mathrm{DBH})$ were measured and identified. A total of 1,398 stems were enumerated in study areas. Basal area of sampled trees was determined. From the analysis of variance, it was found that the difference in the means of the basal area of trees between study sites were not statistically significant at POO.05. The forest stand structure described by diameter distribution was inverse $\mathrm{J}$-shaped which indicates the stands are developing and regeneration in the forest is present in the study areas. Information from this study may provide a valuable reference for forest assessment as well as ecotourism planning and management.
\end{abstract}

Keyword: Ecotourism; Forest stand structure; Basal area; Taman Negara Pahang 